Artigo Original

\title{
Nitroxides Improve Biochemical Profiling and Prevent Injuries in the Organs of Type 1 Diabetic Rats
}

\author{
Anelise R Brito ${ }^{a}$, Gabriela F Ravazi ${ }^{a}$, Ana PP de Oliveira ${ }^{a}$, Cláudio Daniel Cerdeira ${ }^{\text {* }}$, \\ Bruno CC Salles ${ }^{\mathrm{b}}$, Eduardo P Camara ${ }^{\mathrm{a}}$, Jyean Muchon ${ }^{\mathrm{a}}$, Gabriel OI Moraes ${ }^{\mathrm{b}}$, Fernanda BA Paula $^{\mathrm{c}}$, \\ Maísa RPL Brigagão ${ }^{\mathrm{b}}$, Gérsika B Santos ${ }^{\mathrm{a}}$ \\ ${ }^{a}$ Research Laboratory in Biological Sciences, José do Rosário Vellano University (Unifenas), Alfenas, Minas Gerais, Brazil. \\ ${ }^{b}$ Faculty of Biomedical Sciences, José do Rosário Vellano University (Unifenas), Alfenas, Minas Gerais, Brazil. \\ 3Laboratory of Clinical Biochemistry, Department of Clinical and Toxicological Analysis, Faculty of Pharmaceutical Sciences, Federal University of Alfenas, Minas Gerais, Brazil.
}

INFORMAÇÃO SOBRE O ARTIGO

Historial do artigo:

Received/ Recebido: 2017-12-29

Accepted/Aceite 2019-04-22

Online: 2020-01-22

(C) Autor (es) (ou seu (s) empregador (es)) 2019.

Reutilização permitida de acordo com

(C) Author(s) (or their employer(s)) 2019.

Re-use permitted under CC BY-NC.

No commercial re-use.

\section{Keywords:}

Antioxidants;

Diabetes Mellitus Experimental;

Rats Wistar.
CC BY-NC. Nenhuma reutilização comercial.

A B S T R A C T

Introduction: Diabetes mellitus (DM) is still considered a major public health concern worldwide and lacks new and safe drugs for long-term and/or adjuvant therapy. Thus, we postulated that nitroxides could prevent DM complications in rats.

Methods: To evaluate the effects of the nitroxides tempo and tempol in preventing hyperglycemia, heart damage, DM-associated oxidative stress-induced renal injury, and other DM complications, nitroxides $(30 \mathrm{mg} / \mathrm{kg} / \mathrm{day})$ were fed to Wistar rats with alloxan-induced type $1 \mathrm{DM}$ for 60 days. The animals were then evaluated for glucose levels, lipid peroxidation in the kidneys, biochemical parameters of renal function (creatinine levels), liver function (aspartate aminotransferase [AST] and alanine aminotransferase [ALT] total lipids, and steatosis), and lipid profiling (total cholesterol and fractions), and a histological analysis of the kidneys, liver, heart, and eyes was performed.

Results: Treatment of the diabetic rats with tempo or empol prevented hyperglycemia $(p<0.01)$. Interestingly, only tempo was able to prevent lipid peroxidation in the kidneys of the diabetic rats $(p$ $<0.01)$, while also decreasing creatinine levels $(p<0.05)$. In contrast, tempol prevented damage in the liver, kidneys, eyes, and heart of diabetic rats $(p<0.01)$ and showed evidence of preventing left ventricular hypertrophy. Notably, tempol and tempo prevented any significant increase in ALT levels and in the amount of total lipids in the liver of the diabetic rats.

Conclusion: tempo and tempol presented great potential for preventing hyperglycemia and its complications in rats, both of which decreased markers of liver dysfunction. Tempo also mitigated oxidative damage to the kidneys, while tempol considerably attenuated heart injury.

\section{Nitróxidos Melhoram os Parâmetros Bioquímicos e Previnem ILesões em Orgãos de Ratos com Diabetes Mellitus Tipo 1}

Palavras-chave:

Diabetes Mellitus Experimental;

Ratos Wistar.

Introdução: A diabetes mellitus (DM) ainda é considerada uma das principais preocupações de saúde pública em todo o mundo e carece de medicamentos novos e seguros para uma terapia de longo prazo e/ou adjuvante. Assim, postulamos que os nitróxidos poderiam prevenir as complicações do DM em ratos.

Métodos: Para avaliar os efeitos dos nitróxidos tempo e tempol na prevenção de hiperglicemia, lesão cardíaca, lesão renal induzida por estresse oxidativo e outras complicações do DM, os nitróxidos (30 $\mathrm{mg} / \mathrm{kg} / \mathrm{dia}$ ) foram administrados durante 60 dias a ratos Wistar com DM tipo 1 induzido por

\footnotetext{
* Autor Correspondente / Corresponding Author.

E-Mail: claudio.cerdeira@unifenas.br (Cláudio Daniel Cerdeira)

Faculty of Biomedical Sciences, José do Rosário Vellano University (Unifenas/Alfenas),

MG-179, Km 0, 37132-440, Alfenas, Minas Gerais, Brazil.
} 
aloxano. Os animais foram em seguida avaliados quanto à glicemia, peroxidação lipídica nos rins, parâmetros bioquímicos da função renal (creatinina), função hepática (aspartato aminotransferase [AST] e alanina aminotransferase [ALT] lipídios totais e esteatose) e perfil lipídico (colesterol total e frações), e uma análise histológica dos rins, fígado, coração e olhos.

Resultados: O tratamento dos ratos diabéticos com tempo ou tempol preveniu a hiperglicemia ( $p<$ $0,01)$. Curiosamente, apenas tempo foi capaz de prevenir a peroxidação lipídica nos rins dos ratos diabéticos $(p<0,01)$, enquanto que também diminuiu os níveis de creatinina $(p<0,05)$. O Tempol preveniu danos no fígado, rins, olhos e coração de ratos diabéticos $(p<0,01)$ e mostrou-se efetivo na prevenção da hipertrofia ventricular esquerda (HVE). Notavelmente, tempol e tempo impediram qualquer aumento significativo nos níveis de ALT e na quantidade de lipídios totais no fígado dos ratos diabéticos.

Conclusão: Tempo e tempol apresentaram grande potencial para prevenir a hiperglicemia e suas complicações em ratos com DM tipo 1, sendo que ambos os nitróxidos preveniram o aumento de marcadores de disfunção hepática. O nitróxido tempo também impediu o dano oxidativo aos rins, enquanto que tempol atenuou consideravelmente a lesão cardíaca.

\section{Introduction}

Diabetes mellitus (DM) is a group of endocrine and metabolic diseases affecting carbohydrate metabolism and is defined by elevated glycemic markers. The genesis of DM can occur from impaired insulin secretion by the pancreas (type $1 \mathrm{DM}$ or insulindependent DM), resistance to insulin action (type 2 DM or noninsulin-dependent DM), or both. Currently, DM is still considered a major public health concern worldwide and is one of the leading causes of death globally. ${ }^{1-3}$

Complications from DM are divided into microvascular (e.g., retinopathy, blindness, nephropathy, and neuropathy) and macrovascular (heart attacks/injury, left ventricular hypertrophy [LVH], strokes, and peripheral vascular disease). ${ }^{4}$ The associated nephropathy is one of the most serious and common microvascular complications of DM, and it is considered the leading cause of chronic renal failure (CRF) as well as the main indication for dialysis and transplantation. Approximately $30 \%$ of patients with DM develop diabetic nephropathy. Throughout the world, this chronic complication of DM affects approximately $25 \%$ of individuals with type $1 \mathrm{DM}$ and approximately $5 \%$ to $10 \%$ with type $2 \mathrm{DM}^{3}$

During the development of chronic diseases such as DM (including diabetic heart disease [DHD]), the increase in production of reactive oxygen/nitrogen species (ROS/RNS) is remarkable, and the consequent so-called "oxidative stress" and oxidative tissue damage are common. ${ }^{5,6}$ Indeed, for long-term complications of DM, oxidative stress, inflammation, and the formation of advanced glycation end-products (AGEs) have been reported. Thus, hyperglycemia in uncontrolled DM is known to induce oxidative stress through glucose-induced ROS, which can cause oxidative damage in the kidneys and heart. ${ }^{5-7}$ Recent studies have revealed the important contribution of renal oxidative stress in the pathogenesis of diabetic nephropathy and chronic kidney disease. ${ }^{8,9}$ Among ROS, the superoxide (O2-•) is critically important in the regulation of renal function through diverse mechanisms related to the control of blood pressure..$^{10}$

Nicotinamide adenine dinucleotide phosphate (NADPH) oxidase complex (i.e., Nox1, 2, and 4) is the largest source of O2-• in the kidneys, ${ }^{11,12}$ but mitochondrial overproduction of $\mathrm{O} 2-\bullet$ also leads to considerable oxidative stress. Oxidants (including O2-•) are produced in the kidneys by fibroblasts, endothelial cells, vascular smooth muscle cells, mesangial cells, tubular cells, and podocytes. ${ }^{11}$ Furthermore, the presence of an inflammatory process in the kidneys and/or hyperglycemia can result in the priming of neutrophils, activating the oxidative burst of these cells (i.e., activation of Nox2 system) and forming O2-•, which leads to the formation of other ROS/RNS. ${ }^{13}$ NADPH oxidase expression is in- creased in the glomeruli and distal tubules in experimental models of DM with nephropathy. ${ }^{14}$ Mesangial cells express p22 ${ }_{\text {phox }}$ and $\mathrm{p} 47_{\text {phox }}$, and the activity of these subunits in a high-glucose medium has been implicated in the oxidative stress associated with the pathogenesis of diabetic nephropathy. ${ }^{15-17}$

Moreover, in another chronic complication from DM, a decrease in the human body's antioxidant defense (i.e., superoxide dismutase [SOD], catalase, and glutathione [GSH]) can occur with this condition and synergize with the oxidative damage experienced by patients with DM. Therefore, improving the antioxidant system through a combination therapy with exogenous antioxidants may represent an important alternative for treating and/or preventing diabetic nephropathy or other DM complications caused by oxidative stress.

Since 1964, when Emmerson and Howard-Flanders reported that nitroxides could provide radioprotection vis-à-vis lethal effects of radiation, the recognized therapeutic potential of these compounds has been extensively studied, and currently, these studies are taking place in the medical field, where several bioactivities have been described. ${ }^{18-20}$ By reactions involving the transfer of electrons, nitroxides can be reduced to hydroxylamines or oxidized to oxoammonium cations, with an ability to react directly or indirectly with ROS/RNS, thus being able to protect cells, tissue, and organs from damage induced by oxidants. ${ }^{18-20,21}$

Among the stable nitroxide radicals, the spin label 2,2,6,6-tetramethylpiperidine 1-oxyl (tempo) and its water-soluble analogue, 4-hydroxy-2,2,6,6-tetramethylpiperidine 1-oxyl (tempol) (Fig. 1), are powerful scavengers of ROS/RNS, with outstanding SOD-like activity and pleiotropic effects, which differs greatly from monofunctional antioxidants that mainly operate via a single mechanism. These compounds could have great relevance in the management of diabetic patients by controlling DM complications, such as nephropathy, in which ROS/RNS contribute to the oxidative damage. Indeed, since hyperglycemia is known to induce oxidative stress through the increased production of ROS/ RNS, the antioxidant action of nitroxides could lead to a decrease in these oxidants, which lowers the risk of oxidant attacks on vital macromolecules and hence avoiding lipid peroxidation, protein oxidation, DNA damage, and the irreversible formation of AGEs. ${ }^{22}$

Thus, the objective of this study was to evaluate, in Wistar rats with type $1 \mathrm{DM}$, the ability of the nitroxides tempol and tempo to prevent hyperglycemia, oxidative damage in the kidneys, and other complications from DM, including renal dysfunction (as indicated by creatinine levels), liver dysfunction (as indicated by ALT, AST, and steatosis), heart injury (direct damage and LVH), and lipid profiling (total cholesterol and fractions). 
a. Tempo<smiles>CC1(C)CCCC(C)(C)N1[O]</smiles>

b. Tempol<smiles>CC1(C)CC(O)CC(C)(C)N1[O-]</smiles>

Figure 1. Chemical structures of Tempo (a.) and Tempol (b.), where the unpaired electron centered on the nitroxide group is highlighted.

\section{Material and methods}

\section{Experimental procedures \\ Animals}

In this study, 60 healthy 6-9-week-old male Wistar rats (Rattus norvegicus) weighing 250-350 g, were used. The animals were supplied by the breeding colony of the University José do Rosário Vellano and were housed with a controlled temperature $\left(25 \pm 1^{\circ} \mathrm{C}\right)$ in a light-controlled room with a $12 \mathrm{~h}$ light/dark cycle. All the animals were kept in collective cages, totaling six animals per cage, and were fed a standard diet (commercial feed) and water ad libitum. The animals underwent a 10-day period of acclimatization.

\section{Induction of type 1 diabetes mellitus (DM)}

Briefly, according to the methodology described by Lerco et $a l,{ }^{23}$ the animals were randomly divided into five groups, with 12 animals per group, and maintained on a fasting diet for 12 hours (with only water given ad libitum), and then the test animals (groups 2 to 5$)$ received a single dose $(150 \mathrm{mg} / \mathrm{kg}$, intraperitoneally) of a solution of alloxan monohydrate (Sigma-Aldrich Inc., St. Louis, MO, USA). In the control group (group 1), the animals received a single dose of $0.9 \%$ saline. One and a half hours later, the supply was reintroduced. Seven days later, weighing of the animals and the determination of blood glucose levels were performed. Those rats in which the plasma glucose levels exceeded $250 \mathrm{mg} / \mathrm{dL}$ were considered diabetic, as shown in Fig. 2.

\section{Experimental design}

The experimental design is presented in Table 1, and its schematic representation is depicted in Fig. 2.

\section{Biological samples}

After 60 days of treatment, the animals were maintained on a fasting diet for 12 hours and then were anesthetized (ketamine [40 $\mathrm{mg} / \mathrm{kg}$, Bayer AS and Parke-Davis ${ }^{\circledR}$, Berlin - Bayer, Leverkusen, Germany] and xylazine [6 mg/kg, Bayer AS and Parke-Davis ${ }^{\circledR}$ ), and the blood was collected. The animals were then euthanized, and the organs were removed. The heart was removed via a thoracotomy, in which $1.34 \mathrm{mM} \mathrm{KCl}(6 \mathrm{~mL})$ was injected into the rats' hearts through the left ventricle (LV), and then this organ was removed. After sagittal incision, the kidneys, eyes, and liver were also removed and fixed in 10\% neutral-buffered formalin (24 hours), before histological analysis.
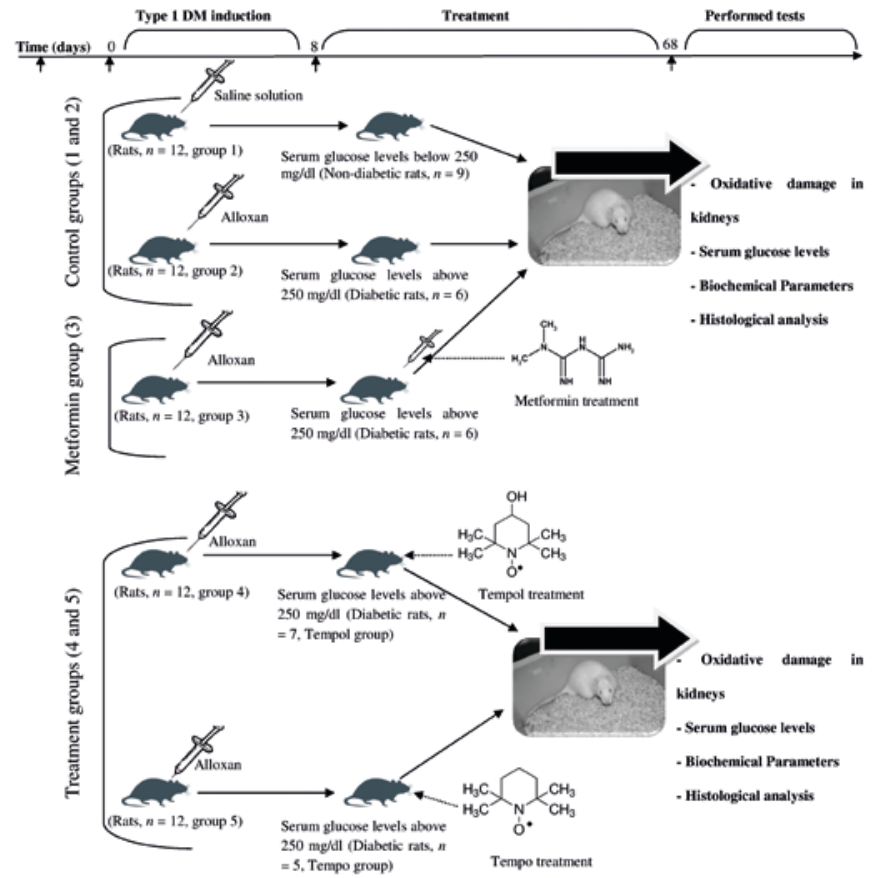

Figure 2. Outline of the experimental design.

Subtitle: Sixty healthy Wistar rats were divided into five groups (12 animals per group). Next, using alloxan $(150 \mathrm{mg} / \mathrm{kg}$, intraperitoneally, single dose), type 1 diabetes mellitus (DM) was induced in groups 2 to 5 (first week). After that, the animals were fed and watered ad libitum, and Tempo and Tempol (30 mg nitroxide $/ \mathrm{kg} /$ day) was given by gavage to groups 5 and 6 , respectively, for two months. Next, the animals were tested for oxidative damage (kidneys), serum glucose levels, biochemical parameters, and histological analysis (eyes, liver, kidneys, and heart). In the control group, treatment with metformin $(50 \mathrm{mg} / \mathrm{kg} /$ day) for 60 days in group 3 was performed.

\section{Preparation of tissue homogenates}

The kidney homogenate was prepared as described by Jones et $a l .^{24}$ The kidneys were removed and homogenized (at $4^{\circ} \mathrm{C}$ ) in 0.1 $\mathrm{M}$ phosphate buffered saline (PBS, $\mathrm{pH} 7.2$ ) at the rate of $5 \mathrm{~mL} / \mathrm{g}$ kidney. This homogenate was centrifuged $\left(3000 \mathrm{~g}, 10 \mathrm{~min}, 4^{\circ} \mathrm{C}\right)$, and the supernatant was subsequently used.

\section{Analysis of blood glucose levels, lipid profiling, renal function, and liver function}

Briefly, the biochemical parameters associated with type 1 DM complications were measured using standard methods and commercial kits. The blood glucose levels and total cholesterol (TC) or fractions (Triglycerides [TG] and high-density lipoprotein $[\mathrm{HDL}]$ ) were determined in the serum through the endpoint colorimetric method. The serum creatinine levels (renal function) were determined by the modified Jaffe method, and the measurement procedure was calibrated with the standard reference material (SRM) 914a of the National Institute of Standards and Technology (NIST). To evaluate the liver function, the levels of the enzymes aspartate aminotransferase (AST) and alanine aminotransferase (ALT) in the serum were determined by the UVkinetic method. The total lipid concentration in the liver homogenates was determined by using the Bligh Dyer method, and the results were reported as total lipids (\%), which represented the total lipid percentage per $\mathrm{mL}$ of liver homogenate. ${ }^{25}$

\section{Evaluation of lipid peroxidation in the kidneys}

To evaluate the oxidative insult to lipids, the peroxidation products that reacted with thiobarbituric acid (TBA) were measured through the thiobarbituric acid-reactive species (TBARS, oxidative stress byproducts) assay, as described by Winterbourn 
Table 1. Experimental groups

\begin{tabular}{|c|c|c|c|c|c|}
\hline Group & $\begin{array}{c}\mathrm{N}^{\circ} \text { initial of } \\
\text { animals }\end{array}$ & $\begin{array}{c}\text { DM } \\
\text { induction }\end{array}$ & $\begin{array}{l}\mathrm{N}^{\circ} \text { of animals } \\
\text { after induction } \\
\text { of DM }\end{array}$ & Treatment & $\begin{array}{l}\mathrm{N}^{0} \text { of animals } \\
\text { that completed } \\
\text { the study }\end{array}$ \\
\hline 1: Control, rats without DM & 12 & $0.9 \%$ saline & 9 & ---- & 9 \\
\hline 2: Control, diabetic rats & 12 & Alloxan & 6 & ---- & 6 \\
\hline 3: Diabetic rats treated with metformin & 12 & Alloxan & 6 & Metformin & 6 \\
\hline 4: Diabetic rats treated with Tempol & 12 & Alloxan & 7 & Tempol & 7 \\
\hline 5: Diabetic rats treated with Tempo & 12 & Alloxan & 5 & Tempo & 5 \\
\hline
\end{tabular}

et al. ${ }^{26}$ The aliquots $(150 \mu \mathrm{L})$ of the homogenate from the kidneys were mixed with $1.22 \mathrm{M}$ phosphoric acid $(750 \mu \mathrm{L})$, deionized water $(1350 \mu \mathrm{L})$, and TBA $(0.67 \%, 750 \mu \mathrm{L})$; the mixture was then incubated. Next, the incubation mixture was boiled in water for 1 hour at $95^{\circ} \mathrm{C}$. After cooling in an ice bath $\left(4^{\circ} \mathrm{C}\right)$, methanol $(1800$ $\mu \mathrm{L}), 1 \mathrm{M} \mathrm{NaOH}(200 \mu \mathrm{L})$, and the sample $(1000 \mu \mathrm{L})$ were added to a cuvette. The concentration of TBARS was estimated from the standard curve of malonic dialdehyde (MDA; from the hydrolysis of 1,1,3,3 tetramethoxypropane). The MDA levels were quantified using a Varian Cary Eclipse spectrofluorometer ( $\lambda$ excitation $=532 \mathrm{~nm} ; \lambda$ emission $=563 \mathrm{~nm})$. The results were expressed as $\mu \mathrm{g} \mathrm{MDA} / \mathrm{mol}$ of protein. The total protein concentration was determined by the Bradford method. ${ }^{27}$

\section{Histological analysis of the organs}

To evaluate morphological changes of the heart, liver, kidneys, and eyes, the rat hearts were dissected, and the left ventricles were fixed in 10\% neutral-buffered formalin (48 hours); then, the fixed specimens were processed by the conventional paraffin-embedding technique. ${ }^{28} \mathrm{~A}$ series of sections of $3 \mu \mathrm{m}$ thicknesses were taken in the same plane and deposited on the slides, stained with hematoxylin and eosin (H\&E) or Masson-trichrome (sections of LV) and then were morphologically analyzed with an optical microscope (Nikon, TNB-04T-PL, magnifications $40 \mathrm{x}$ or $100 \mathrm{x}$ ). The measurement of the left ventricular amplitude followed the standard criteria using the software LGMC-image, version 1.0. All the histological analyses were performed by a single examiner, using the double-blind method.

\section{Data analysis}

All the graphs were constructed using BioEstat software (version 5.0, Belém, Pará, Brazil, 2007) and, except where otherwise noted, the results are expressed as the mean \pm standard deviation (SD) and are representative of three independent experiments, at least in triplicate. Analysis of variance (ANOVA), followed by Tukey's or Bonferroni's tests for multiple comparisons of the means, was also performed using BioEstat software. The means were considered significantly different with $p$ values of less than $0.05(\alpha=0.05)$. The chemical structures depicted in this study were constructed using software from ACD/Labs (Advanced Chemistry Development, Inc., version 6.0).

\section{Results}

Effects of nitroxides on body weights of the diabetic animals

The average weights for the different experimental groups are shown in Table 2. Tempol or tempo treatment did not influence animal weight between groups as well as within groups (after final treatment).

\section{Effects of nitroxides on glycemia}

The blood analyses for the glucose levels of the animals with the different treatments are shown in Fig. 3. The blood glucose levels of the diabetic induction group were significantly higher than the non-diabetic group, whereas both tempo and tempol treatments $(30 \mathrm{mg} / \mathrm{kg} / \mathrm{day})$ were significantly anti-hyperglycemic in the diabetic rats compared to the untreated diabetic rats.

Table 2. Lipid profile (Serum levels of total cholesterol and fractions [triglycerides and HDL]), total lipids in liver, and weight for the experimental groups

\begin{tabular}{|c|c|c|c|c|c|}
\hline \multicolumn{2}{|c|}{ Rats without DM } & \multicolumn{4}{|c|}{ Diabetic rats } \\
\hline & & \multicolumn{4}{|c|}{ TREATMENTS } \\
\hline & - & 一 & Metformin & $\underset{\mathrm{OH}}{\text { Tempol }}$ & Tempo \\
\hline Cholesterol (mg/dL) & $69.678^{a}$ & $67.525^{\text {a }}$ & $64.26^{\mathrm{a}}$ & $63.5325^{a}$ & $66.92^{a}$ \\
\hline Triglycerides (mg/dL) & $50.5^{\mathrm{a}}$ & $68.5^{\text {a }}$ & $58.5^{\text {a }}$ & $67.5^{a}$ & $48.6^{\mathrm{a}}$ \\
\hline HDL (mg/dL) & $26^{\mathrm{a}}$ & $25.25^{\text {a }}$ & $27.6^{\mathrm{a}}$ & $23.25^{\mathrm{a}}$ & $34^{\text {a }}$ \\
\hline Total lipids in liver (\%) & $1.28^{\mathrm{b}}$ & $1.48^{\mathrm{c}}$ & $1.05^{\mathrm{a}}$ & $1.15^{\mathrm{a}}$ & $0.99^{\text {a }}$ \\
\hline Weight1 (g)* & $353^{\mathrm{a}, \mathrm{A}}$ & $3393^{\mathrm{a}, \mathrm{A}}$ & $365^{\mathrm{a}, \mathrm{A}}$ & $303^{\mathrm{a}, \mathrm{A}}$ & $291^{\mathrm{a}, \mathrm{A}}$ \\
\hline Weight2 (g) & $382^{\mathrm{b}, \mathrm{A}}$ & $3113^{\mathrm{a}, \mathrm{A}}$ & $361^{\mathrm{b}, \mathrm{A}}$ & $315^{\mathrm{a}, \mathrm{A}}$ & $276^{a, A}$ \\
\hline
\end{tabular}

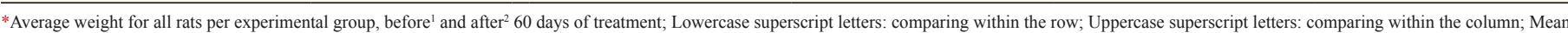
values with different letters are significantly different $(p<0.05)$. $\mathrm{HDL}=$ high-density lipoprotein; $\mathrm{DM}=$ type 1 diabetes mellitus 


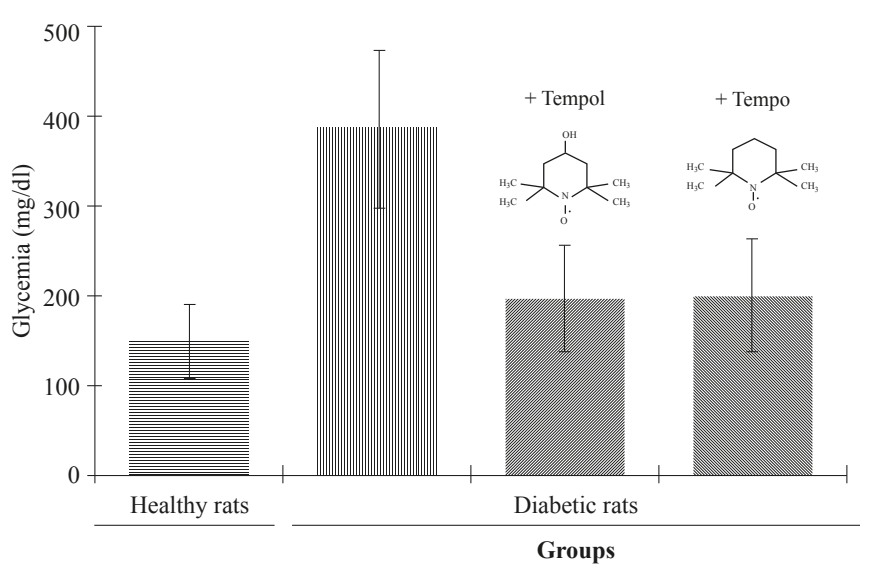

Figure 3. Influence of the nitroxides on blood glucose levels (mg/dL).

Mean values for the serum glucose levels were $149.8 \pm 41.55 \mathrm{mg} / \mathrm{dL}$ in rats without DM, whereas in groups of rats with type $1 \mathrm{DM}$, the levels were significantly $(p<0.01)$ higher $(387.25 \pm 89.31 \mathrm{mg} / \mathrm{dL}$. Treatment of the diabetic rats with $30 \mathrm{mg} / \mathrm{kg} /$ day Tempol or Tempo significantly decreased blood glucose levels ( $197.33 \pm 59.53 \mathrm{mg} / \mathrm{dL}$ and $200.4 \pm 63.03$, respectively) relative to the untreated diabetic rats $(p<0.01)$. There was no significant difference between Tempol and Tempo treatments $(p=$ NS). $\neq$ : \pm standard deviation; Mean values are significantly different when $p<0.05(\alpha=0.05)$.

\section{Effects of nitroxides on oxidative damage in the kidneys as well as renal function and morphology}

Interestingly, only tempo was able to prevent a significant increase in creatinine levels in the diabetic rats relative to the untreated diabetic rats (Fig. 4A.). As observed in Fig. 4B., a high degree of glucose-induced lipid peroxidation was observed in the diabetic rats compared with the non-diabetic rats. Notably, when compared with the untreated diabetic rats, tempo treatment $(30 \mathrm{mg} / \mathrm{kg} / \mathrm{day})$ prevented lipid peroxidation significantly in the kidneys. In contrast, treatment of the diabetic rats with $30 \mathrm{mg} / \mathrm{kg} /$ day of tempol did not affect

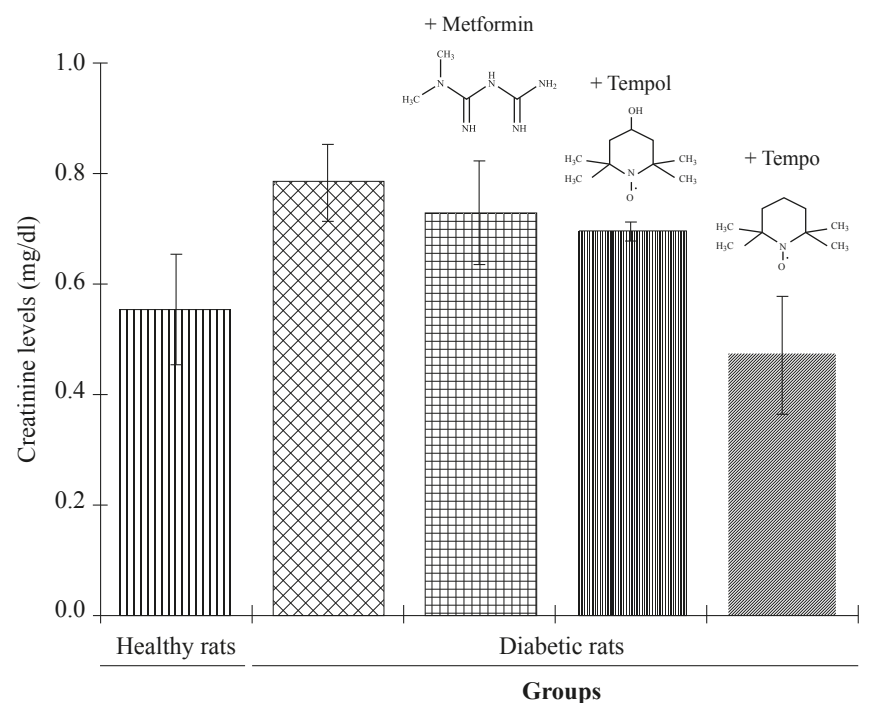

Figure 4. Effects of the nitroxides on renal morphology and function and oxidative damage in the type 1 diabetic rats.

A. Creatinine levels were significantly different between the rats without DM and the diabetic rats $(\mathrm{p}<0.05)$. Diabetic rats treated with Tempo $(30 \mathrm{mg} /$ $\mathrm{kg}$ per day) had lower serum creatinine levels $(p<0.05)$ compared with the untreated diabetic rats. Metformin or Tempol treatment did not prevent the increase in serum creatinine levels $(p=\mathrm{NS})$.

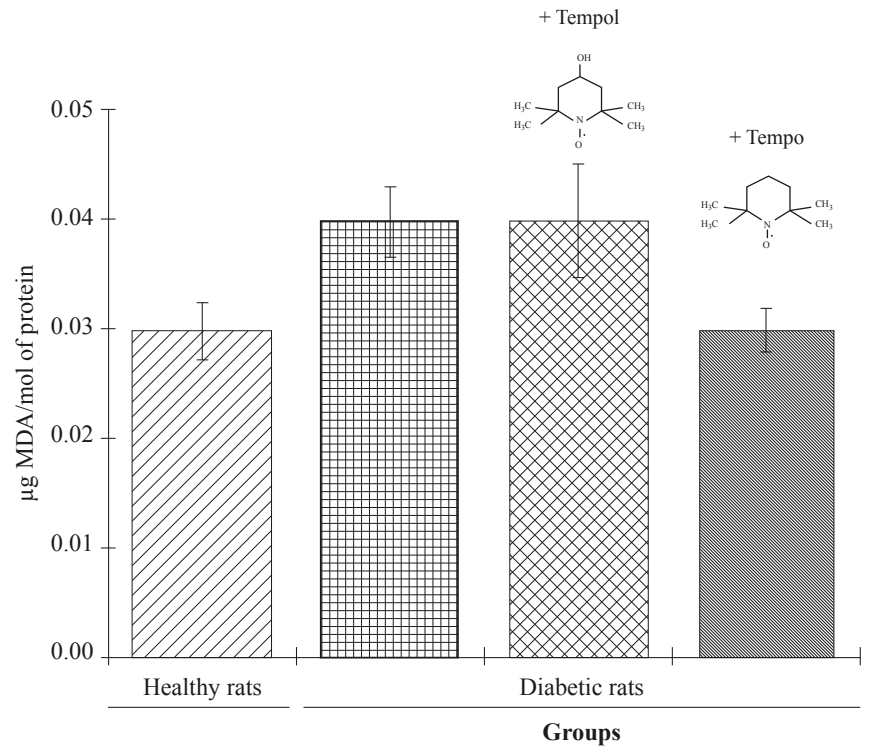

B. Lipid peroxidation was significantly higher in the kidneys of the diabetic rats compared with the rats without DM $(p<0.01)$. Treatment of diabetic rats with Tempo $(30 \mathrm{mg} / \mathrm{kg}$ per day) significantly $(p<0.01)$ prevented lipid peroxidation in the kidneys compared to the untreated diabetic rats. Tempol treatment did not prevent lipid peroxidation in the kidneys of the diabetic rats compared with the untreated diabetic rats $(p=\mathrm{NS})$.
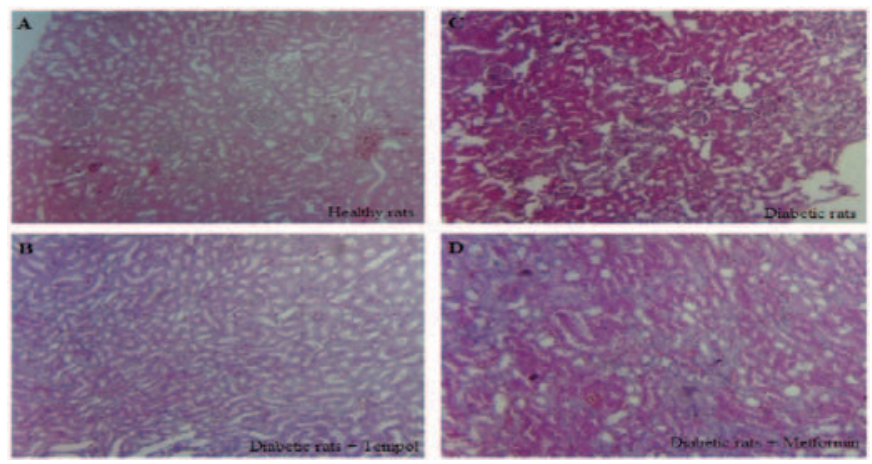

C. Representative sections of the kidneys from rats in the different experimental groups ( $\mathrm{H} \& \mathrm{E}$, magnification is $40 \times)$.
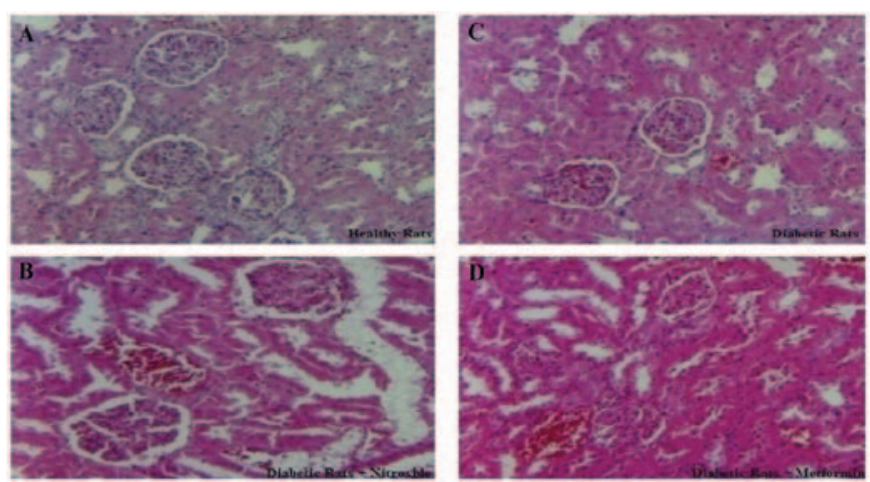

D. Representative sections of the kidneys from rats in the different experimental groups evaluated (H\&E, magnification is $100 \times)$. $\neq: \pm$ standard deviation; Mean values are significantly different when $p<0.05(\alpha=0.05)$.

lipid peroxidation in the kidneys, confirming the findings of the levels of creatinine. The histological analysis of the distal and proximal tubules, Bowman's capsules, urinary tubules, glomeruli bulbs, and Malpighian bodies were assessed (Fig.s 4C. and 4D.). Compared with the healthy rats and tempol-treated diabetic rats, the diabetic rats exhibited nephropathy, with increases in renal fibrosis; cortex damage; 
dilation of the urinary space, the space lying within Bowman\&\#39; capsule, as well as the cortical veins; glomeruli shrinkage; wrinkling of the Malpighian body in some parts; and tubular damage (cell lyses, tubular necrosis, loss of the brush border, cast formation and tubular dilatation at the corticomedullary junction).

\section{Effects of nitroxides on ALT, AST, and liver function and morphology}

Both nitroxides had preventive effects on the increase in ALT levels in diabetic rats (Fig. 5A.), whereas an increase in ALT levels was observed in the untreated diabetic rats when compared to the healthy animals. Neither tempol nor tempo changed the AST levels in diabetic rats relative to the untreated animals (data not shown). In the liver sections, the area around the port, the hepatocytes, the sinusoids, the space around the sinusoids, the interstitial area, and the areas around the central veins were evaluated (Fig. 5B.). There was a difference in the intensity of the hepatic damage. Mild to moderate

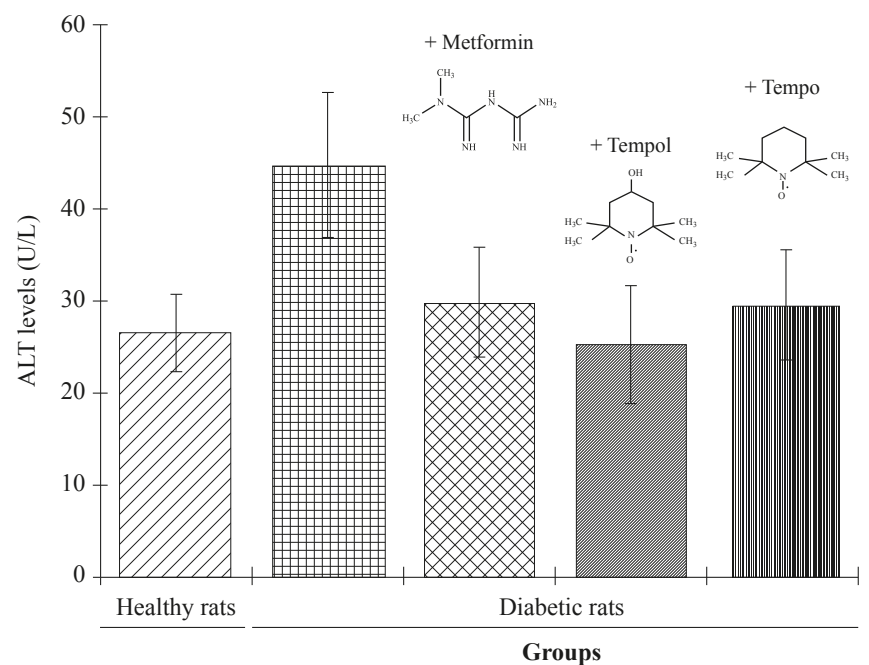

Figure 5. Influence of the nitroxides on liver morphology and function.

A. ALT levels were significantly different between the rats without DM and the diabetic rats $(p<0.01)$. Metformin, Tempol, or Tempo treatment significantly prevented the increase in ALT levels in the serum of the diabetic rats relative to the untreated diabetic rats.
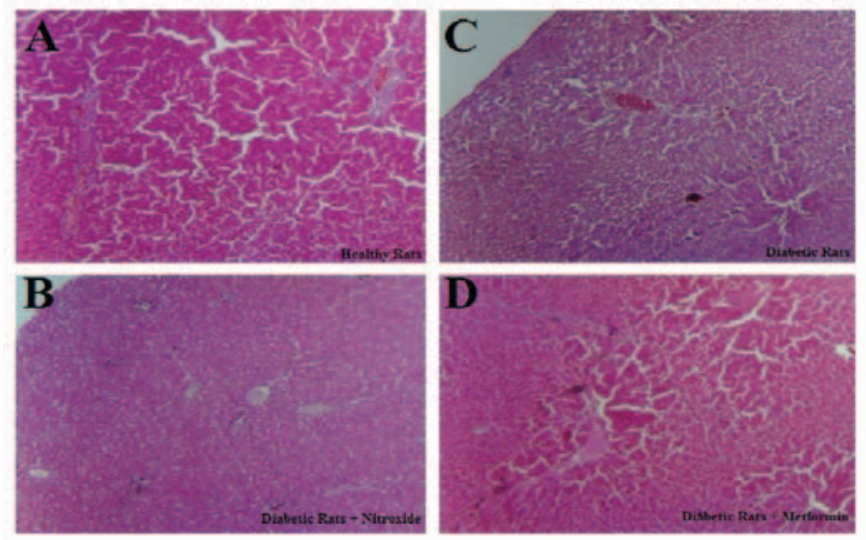

B. Representative sections of the liver from rats in the different experimental groups evaluated (H\&E, magnification is $40 \times$ ). Inflammation (and plasma cell influx) around the portal área, often seen in sinusoid cells around the central vein and sinusoids, occurring also vacuoles in some cells and cellular swelling (hydropic degeneration). Inflated and dilated sinusoid spaces (including parts of the sinusoids that were swollen), and cells that were less eosinophilic (diffuse basophilic focus because of the lower glycogen stores) were observed as well. $\neq: \pm$ standard deviation; Mean values are significantly different when $\mathrm{p}<0.05(\alpha=0.05)$; ALT $=$ alanine aminotransferase. liver fibrosis (around the perisinusoidal spaces and the portal area) was observed in diabetic rats, as well as distortions of the liver architecture, with fatty liver changes (e.g., hepatocytes with fat accumulation, mild-moderate steatosis). The degree of fibrosis observed in the hepatic tissues was lower in the treated groups (metformin or tempol). Clear structures of the hepatic lobules and hepatocytes radially arranged around the central vein, as well as no obvious inflammatory cell infiltration (or plasma influx) or Kupffer cell proliferation, appeared in the control and tempol-treated groups.

\section{Effects of nitroxides on lipid profiling}

The total cholesterol, triglycerides, and HDL did not change significantly in the diabetic rats compared to the non-diabetic rats (Table 2). However, the percentage of total lipids increased sig-

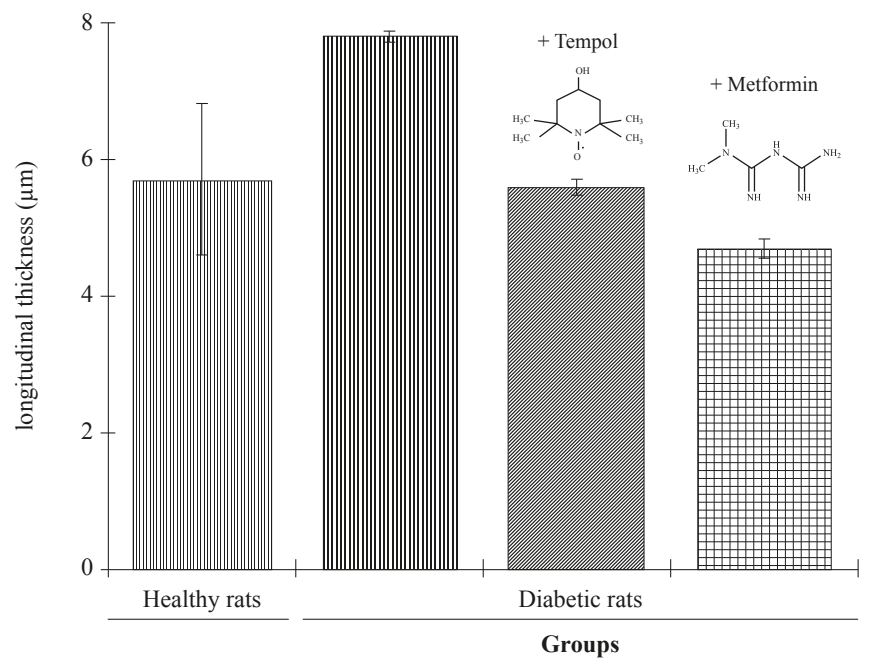

Figure 6. Left ventricular dimensions (left ventricular wall thickness, in $\mu \mathrm{m}$ ) and cardiac morphology in the evaluated groups.

A. Diabetic and non-diabetic rats were significantly different regarding their left ventricular dimensions $(p<0.01)$. Tempol or metformin treatment significantly $(p<0.01)$ prevented left ventricular hypertrophy (LVH) in the diabetic rats compared to the untreated diabetic rats. $\neq: \pm$ standard deviation; Mean values are significantly different when $p<0.05(\alpha=0.05)$.
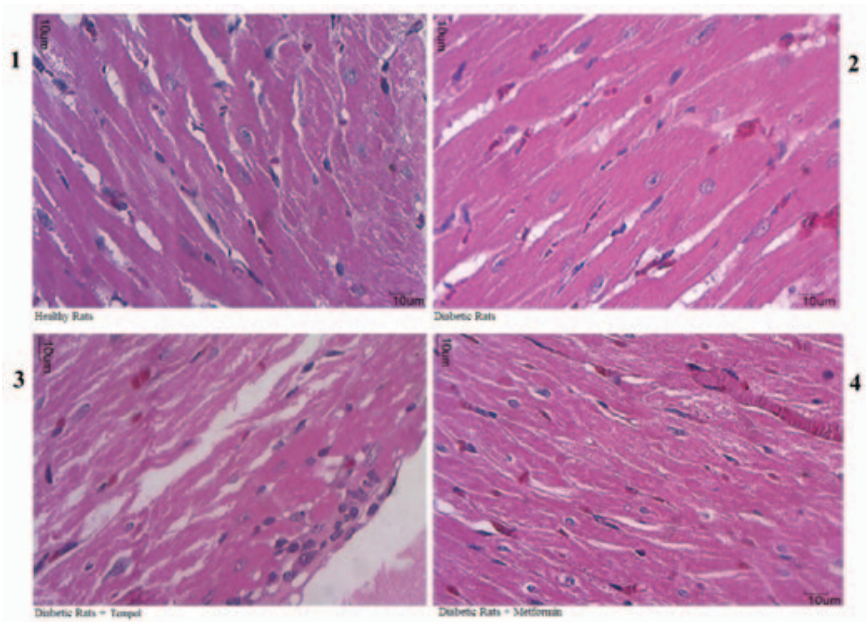

B. Magnification $(100 \times)$ of the hearts from rats in the different experimental groups. Representative photomicrographs of the healthy rats (normal cardiomyocytes [1]) were compared to those from the rats presenting disparate pathological changes (cardiac hypertrophy [2]). DM-induced cardiac hypertrophy was attenuated by Tempol [3] or metformin treatment [4]. Scale bars, $10 \mu \mathrm{m}$. 
nificantly in the liver of the diabetic rats compared to the nondiabetic rats, whereas tempo or tempol (30 mg/kg/day) treatment lowered the levels of total lipids in the diabetic rats compared with the untreated diabetic rats (Table 2), thus confirming the histological findings in the liver sections.

\section{Influence of the nitroxide tempol on heart morphology}

The positive effects of tempol on the attenuation of cardiac injury included the prevention of the LVH (analysis of left ventricular thickness) in diabetic rats, and they are shown in Fig.s 6A and 6B. The global left ventricular thickness (Fig. 6A.) was decreased by this nitroxide, confirmed further in Fig. 6B. (normal cardiomyocytes, photomicrograph 3 ). This positive effect was also elicited by metformin treatment (Fig. 6A. and B. [photomicrograph 4]).

\section{Effects of the nitroxide tempol on rat eyes}

In comparing the eye sections, the ganglion cell layer, the inner nuclear layer, the outer nuclear layer, and the choroid were evaluated (Fig. 7). In the eyes, alterations were observed in the untreated diabetic rats, whereas tempol or metformin treatment relieved these types of damages in diabetic rats, which was further attested by the macroscopic observation of the eyes (data not shown).

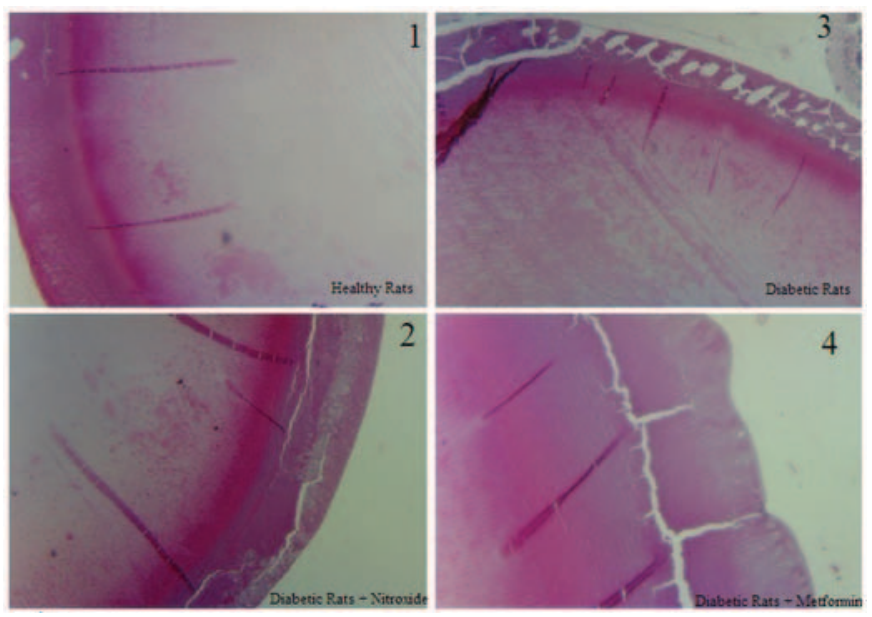

Figure 7. Histological analysis of rat eyes.

Magnification $(100 \times)$ of H\&E-stained sections of the eyes from rats in the different experimental groups.

\section{Discussion}

In this study, we undertook the testing of the nitroxides tempo and tempol-SOD mimetics and pleiotropic antioxidants - as anti-hyperglycemic agents that prevent DM complications, such as oxidative damage in the kidneys, liver dysfunction, and eye and heart injuries. The effects of these synthetic antioxidants administered by gavage at a dosage of $30 \mathrm{mg} / \mathrm{kg} /$ day for 60 days were evaluated in a rat model of type $1 \mathrm{DM}$. Treatment of the diabetic rats with tempol or tempo decreased the blood glucose levels approximately two-fold.

It has been reported that tempol increases glucose transport and glucose uptake by cells. ${ }^{29}$ According to Shahidi et al, ${ }^{2}$ tempol can decrease plasma glucose levels and improve lipid profiling in an experimental animal model using Wistar rats with streptozotocininduced diabetes, in which rats were fed this nitroxide $(30 \mathrm{mg} / \mathrm{kg}$ / day) for 60 days. However, in evaluating the effects of tempol on the pancreas in an experimental acute pancreatitis model using male Wistar albino rats, Erbis et $a l^{30}$ showed that this nitroxide did not lower glucose levels, despite its protective and regenerative effects on the pancreas, with the reestablishment of organ function in rats with acute necrotizing pancreatitis. In our study, nitroxides did not alter body weight. According to Zou et al, ${ }^{31}$ tempol did not normalize body weight or blood glucose in Akita mice, which is a wellestablished animal model of diabetic retinopathy.

Diabetes mellitus is markedly characterized by hyperglycemia and can be associated with dyslipidemia and disturbed liver and kidney functions. Interestingly, although outstanding dyslipidemia did not occur in the rats evaluated in this study, when liver function (ALT levels) was evaluated, increased values of ALT and total lipids were observed in diabetic rats relative to the non-diabetic rats, whereas tempo or tempol treatments prevented these increases. These data are remarkable and demonstrate the effects of the nitroxides on liver function during DM.

The NADPH oxidase-derived ROS are implicated in renal diseases and DHD. ${ }^{3}$ Increased oxidative stress in the kidneys has been recognized in different pathophysiological conditions, such as ischemia-reperfusion, CRF, hypertension, and diabetic nephropathy. Furthermore, it is a well-accepted idea that the high blood glucose-induced overproduction of ROS is present in some diseases, such as renal complications from DM. ${ }^{6,32}$ Cellular injury in renal diseases can be mediated by lipid peroxidation, which causes membrane damage, as well as oxidative modification of other critical intracellular targets. Antioxidants have been shown to protect the polyunsaturated fatty acids (a component of cell membranes) from oxidant attack in diabetes and to end peroxidation events. ${ }^{2}$ In this study, tempo markedly prevented lipid peroxidation in the kidneys of type 1 diabetic rats, whereas the same did not occur when diabetic rats were treated with tempol. The process of lipid peroxidation occurs in three steps. Unlike other antioxidants, nitroxides can inhibit lipid peroxidation by participating in redox reactions at every step, and this bioactivity can be attributed to their property as ROS scavengers, yet these compounds present pleiotropic actions that completely mitigate the renal damage.

The effect of tempo in preventing oxidative stress-induced kidney injury was investigated further by evaluating the parameters of renal injury, including creatinine levels and oxidative stress-induced lipid damage. A profound increase in creatinine levels occurred in diabetic rats when compared to healthy rats. Tempo not only decreased lipid peroxidation (oxidative damage in kidneys) but also prevented an increase in creatinine levels. Curiously, tempol did not prevent oxidative damage in the kidneys, and consequently, creatinine levels increased. These findings are in line with a recent report by Ergin et al, ${ }^{33}$ who demonstrated that tempol does not alleviate lipid peroxidation (MDA levels) in renal tissue in a rat model of renal ischemia/reperfusion by aortic clamping, although the nitroxide alleviated inflammation (decreased Il-6 and iNOS) and kidney injury. Tempo is approximately 200 times more lipophilic than tempol, which may facilitate its accumulation in the cell membrane and explain the effect of this nitroxide in preventing lipid damage.

The effects of nitroxides on renal function have been shown in recent studies. Camacho and Israel $^{34}$ reported that tempol affects kidneys positively by promoting an increase in antioxidant enzyme activities in an experimental model of preeclampsia, a condition in which the role of NO and its dysregulation are highlighted. They showed that tempol improved mean arterial pressure, increased SOD and glutathione peroxidase (GPX) activities, and ameliorated renal function. Additionally, Ding et al, ${ }^{35}$ using a 
model of chronic kidney disease (CKD) induced in mice, demonstrated the effects of tempol on oxidative stress, having observed that this nitroxide inhibited NF- $\kappa ß$-mediated inflammation, transforming growth factor- $\beta$ (TGF- $\beta$ ), and Smad3-induced renal fibrosis; decreased renal markers of oxidative damage and expression of NADPH-oxidase related subunits ( $47_{\text {phox }}, \mathrm{p} 67_{\text {phox }}$, gp9 $1_{\text {phox }}$ ); and prevented activation of the redox-sensitive epidermal growth factor receptor (EGFR) pathway and the mitogen-activated protein kinase (MAPK) (cRaf/MEK/ERK) signaling pathway, accordingly attenuating renal injury in these mice.

The most serious renal lesions have been described as occurring from 3 to 30 weeks after the onset of untreated DM, a time frame covered in this study; considerable morpho-pathological alterations and changes in biomarkers of renal function have been observed at four weeks. ${ }^{36}$ As another example, Banday et $a l,{ }^{37}$ in evaluating the influence of tempol on obese Zucker rats, carried out tests after 15 days of treatments with this nitroxide. Within this time interval, they found that tempol caused a decrease in oxidative stress, an improved sensitivity to insulin, and a restored function of the D1 and G-protein coupling receptors.

Complications of DM include coronary heart disease, which is currently strongly linked to LVH. ${ }^{4}$ As demonstrated in this study, tempol markedly prevented LVH in diabetic rats, further corroborating a similar effect presented by this nitroxide on LVH using an experimental model of LDL receptor gene knockout ( $\mathrm{LDLr}_{-}$) mice with a high-fat diet. ${ }^{28}$ We also demonstrated that metformin (used for treating type $2 \mathrm{DM}$ ) decreased LVH and yet had no antihyperglycemic effect (data not shown). Previous reports relate the positive effects of metformin on preventing types 1 and 2 DMassociated complications, including decreased levels of AGES/ advanced oxidation protein products (AOPPs), oxidative damage, and biochemical parameters, notwithstanding its inability to elicit an anti-hyperglycemic effect on type $1 \mathrm{DM}^{39}$

Chronic alterations of the eye in uncontrolled type 1 DM include retinopathy and blindness, among others. In our study, tempol decreased such alterations in diabetic rats, as also reported by Zarling et $a l^{40}$; Thaler et al, ${ }^{41}$ who evidenced protective effects of tempol on alterations of the eye and proposed the pharmaceutical development of nitroxides that show a potential for treating agerelated degeneration and disease.

Regarding the dosages of nitroxides in the present study, these compounds present very low toxicity in vitro and in vivo, having no toxic effects at a dosages of $30 \mathrm{mg} / \mathrm{kg} / \mathrm{day}^{20}$; thus, their safe use can be justified. Moreover, in this study, no death related to the treatments with the nitroxides occurred (i.e., all of the tempo or tempoltreated animals survived at the $68^{\text {th }}$ day of experiments). Concerning the metabolism, the most common site where the reduction of nitroxides occurs is in the liver's mitochondrial respiratory chain and the microsomal electron transport system, where glucose administration and mitochondrial density (which is related to ROS production) enhance the activity of these systems by increasing the reduction of nitroxides, which could explain the difference in the results between the evaluated nitroxides and could take into account that the renal use of glucose is independent of insulin. ${ }^{20,42,43}$

Our results indicate that, for an experimental alloxan-induced type $1 \mathrm{DM}$, tempo and tempol present anti-hyperglycemic effects, although only tempo ameliorates renal disfunction by reducing oxidative damage and improves renal filtration with a remarkable reduction in creatinine levels, thus shedding light onto new adjuvant therapies for DM. Tempol ameliorated the heart morphological complications (effect on LVH) resulting from DM. The pleiotropic effects of these nitroxides converge on the final beneficial role observed: the primary effects of maintaining blood glucose homeostasis and attenuating lipid peroxidation, as evidenced in this study, as well as the effects reported in earlier studies, such as the control of macrovascular and microvascular changes, the control of key metabolic pathways in the development of DM complications, and the local protective effects on renal circulation as well as for preventing oxidative stress-induced organ injury [especially acting by diminishing NADPH oxidase complex-generated ROS, through mechanisms up-stream of this complex and/or by directly scavenging ROS, according previous studies by our group and others $\left.\left.{ }^{18,20,44,45}\right)\right]$. Therefore, the beneficial activities of these nitroxides may offer new options for pharmacological interventions in the treatment of diseases with excessive ROS/RNS production, such as what occurs during DM complications. The roles of these nitroxides in humans should be investigated further.

\section{Highlights:}

(1) Nitroxides improve biochemical parameters in rats with diabetes mellitus (DM)

(2) Tempo prevents DM-associated oxidative stress-induced renal injury

(3) Tempol abrogates DM-related left ventricular hypertrophy

(4)Tempol prevents eye, liver and renal injuries

Acknowledgments/Agradecimentos: We would like to thank Prof. Ana Claudia Frota Machado de Melo Lopes for a kind help in the analysis of the histological slides.

\section{Responsabilidades Éticas}

Conflitos de Interesse: Conflitos de interesse na realização do presente trabalho.

Fontes de Financiamento: Não existiram fontes externas de financiamento para a realização deste artigo.

Proteção de Pessoas e Animais: Os autores declaram que os procedimentos seguidos estavam de acordo com os regulamentos estabelecidos pelos responsáveis da Comissão de Investigação e Ética. Proveniência e Revisão por Pares: Não comissionado; revisão externa por pares.

\section{Ethical Disclosures}

Conflicts of Interest: The authors report no conflict of interest. Funding Sources: No subsidies or grants contributed to this work. Protection of Human and Animal Subjects: The authors declare that the procedures followed were in accordance with the regulations of the relevant research ethics committee.

Provenance and Peer Review: Not commissioned; externally peer reviewed.

\section{References / Referências}

1. Jabbarpour Z, Shahidi S, Saidijam M, Sarihi A, Hassanzadeh T, Esmaeili R. Effect of tempol on the passive avoidance and novel object recognition task in diabetic rats. Brain Res Bull. 2014;101:51-6.doi: 10.1016/j. brainresbull.2013.12.013.

2. Shahidi S, Jabbarpour Z, Saidijam M, Esmaeili R, Komaki A, Firouzi NH. The Effects of the Synthetic Antioxidant, Tempol, on Serum Glucose and Lipid Profile of Diabetic and Non-Diabetic Rats. Avicenna J Med Biochem. 2016; 4:e31043.

3. U.S. Renal Data System, USRDS 2006 Annual Data Report: Atlas of End-Stage Renal Disease in the United States. Bethesda: National Institutes of Health, National Institute of Diabetes and Digestive and Kidney Diseases; 2006.

4. Eguchi K, Boden-Albala B, Jin Z, Rundek T, Sacco RL, Homma S, et al. 
Association Between Diabetes Mellitus and Left Ventricular Hypertrophy in a Multi-Ethnic Population. Am J Cardiol. 2008;101:1787-91.doi: 10.1016/j.amjcard.2008.02.082.

5. Barbosa JH, Oliveira SL, Seara LT. The role of advanced glycation endproducts (AGEs) in the development of vascular diabetic complications. Arq. Bras Endocrinol Metab. 2008;52:940-50.

6. Baynes JW, Thorpe SR. Role of oxidative stress in diabetic complications: a new perspective on an old paradigm. Diabetes. 1999;48:1-9.

7. Chowienczyk PJ, Brett SE, Gopaul NK, Meeking D, Marchetti M, Russell-Jones DL, et al. Oral treatment with an antioxidant (raxofelast) reduces oxidative stress and improves endothelial function in men with type II diabetes. Diabetologia. 2000;43:974-7.

8. Beisswenger PJ, Drummond KS, Nelson RG,Howell SK, Szwergold BS, Mauer M. Susceptibility to diabetic nephropathy is related to dicarbonyl and oxidative stress. Diabetes. 2005;54:3274-81.

9. Wardle EN. Cellular oxidative processes in relation to renal disease. Am J Nephrol. 2005;25:13-22.

10. Wilcox CS. Reactive oxygen species: roles in blood pressure and kidney function. Curr Hypertens Rep. 2002;4:160-6.

11. Gill PS, Wilcox CS. NADPH oxidases in the kidney. Antioxid Redox Signal. 2006;8:1597-607.

12. Lambeth JD. Nox Enzymes, ROS, and chronic disease: an example of antagonistic pleiotropy. Free Radic Biol Med. 2007;43:332-47.

13. Omori K, Ohira T, Uchida Y, Ayilavarapu S, Batista EL Jr, Yagi M, et al. Priming of neutrophil oxidative burst in diabetes requires preassembly of the NADPH oxidase. J Leukoc Biol. 2008;84:292-301.doi: 10.1189/jlb.1207832.

14. Tojo T, Ushio-Fukai M, Yamaoka-Tojo M, et al. Role of gp91phox (Nox2)-containing $\mathrm{NAD}(\mathrm{P}) \mathrm{H}$ oxidase in angiogenesis in response to hindlimb ischemia. Circulation. 2005;111:2347-2355.

15. Jones SA, Hancock JT, Jones OT, Neubauer A, Topley N. The expression of NADPH oxidase components in human glomerular mesangial cells: detection of protein and mRNA for p47phox, p67phox, and p22 phox. J Am Soc Nephrol. 1995;5:1483-91.

16. Kitada M, Koya D, Sugimoto T, Isono M, Araki S, Kashiwagi A, et al. Translocation of glomerular p47phox and p67phox by protein kinase C-beta activation is required for oxidative stress in diabetic nephropathy. Diabetes. 2003;52:2603-14.

17. Sasaki S, Inoguchi T. The role of oxidative stress in the pathogenesis of diabetic vascular complications. Diabetes Metab J. 2012;36:255-61.

18. Soule BP, Hyodo F, Matsumoto K, Simone NL, Cook JA, Krishna MC, et al. The chemistry and biology of nitroxide compounds. Free Radic Biol Med. 2007;42:1632-50

19. Augusto O, Trindade DF, Linares E, Vaz SM. Cyclic nitroxides inhibit the toxicity of nitric oxide-derived oxidants: mechanisms and implications. An Acad Bras Cienc. 2008;80:179-89.

20. Wilcox CS, Pearlman A. Chemistry and antihypertensive effects of tempol and other nitroxides. Pharmacol Rev. 2008;60:418-69.

21. Samuni AM, Barenholz Y. Site-activity relationship of nitroxide radical's antioxidative effect. Free Radic. Biol. Med. 2003;34:177-85.

22. Tiwari BK, Pandey KB, Abidi AB, Rizvi SI. Markers of oxidative stress during diabetes mellitus.J Biomark. 2013;2013:378790. doi: $10.1155 / 2013 / 378790$.

23. Lerco MM, Spadella CT, Machado JLM, Schellini SA, Padovani CR. Experimental alloxan diabetes-induced: a model for clinical and laboratory studies in rats. Acta Cir Bras. 2003;18:132-42.

24. Jones B, Roberts PJ, Faubion WA, Kominami E, Gores GJ. Cystatin A expression reduces bile salt-induced apoptosis in a rat hepatoma cell line. Am J Physiol. 1998;275:G723-30.

25. AOAC-Association of Official Analytical Chemists, Official Methods of Analysis.16 ed. Washington: AOAC; 1997.

26. Winterbourn CC, Gutteridge JM, Halliwell B. Doxorubicin-dependent lipid peroxidation at low partial pressures of O2. J Free Radic Biol Med. 1985:1:43-9.

27. Bradford MM. A rapid and sensitive method for the quantitation of microgram quantities of protein utilizing the principle of protein-dye binding. Anal Biochem. 1976;72:248-54.

28. Gonçalves ICV, Cerdeira CD, Camara EP, Dias Garcia JA, Ribeiro Pereira LM, Bessa Veloso SR, et al. Tempol improves lipid profile and prevents left ventricular hypertrophy in LDL receptor gene knockout (LDLr-/-) mice on a high-fat diet. Rev Port Cardiol. 2017;36:629-38. doi: 10.1016/j. repc.2017.02.014.

29. Alpert E, Altman H, Totary H, Gruzman A, Barnea D, Barash V, et al. 4-Hydroxy tempol-induced impairment of mitochondrial function and augmentation of glucose transport in vascular endothelial and smooth muscle cells. Biochem Pharmacol. 2004;67:1985-95.

30. Erbis H, Aykotab MR, Ozturkc B, Kabay B, Sungurtekin U, Ozden A, et al. Effects of Tempol on Experimental Acute Necrotizing Pancreatitis Model in Rats. J Invest Surg. 2015;28:268-75. doi: 10.3109/08941939.2015.1037942.

31. Zou MH, Li H, He C, Lin M, Lyons TJ, Xie Z. Tyrosine nitration of prostacyclin synthase is associated with enhanced retinal cell apoptosis in diabetes. Am J Pathol. 2011;179:2835-44. doi: 10.1016/j. ajpath.2011.08.041.

32. Jackson TC, Mi Z, Jackson EK. Modulation of Cyclic AMP Production by Signal Transduction Pathways in Preglomerular Microvessels and Microvascular Smooth Muscle Cells. J Pharmacol Exp Therap. 2004;310:349-58.

33. Ergin B, Bezemer R, Kandil A, Demirci-Tansel C, Ince C. TEMPOL has limited protective effects on renal oxygenation and hemodynamics but reduces kidney damage and inflammation in a rat model of renal ischemia/ reperfusion by aortic clamping. J Clin Transl Res. 2015;1:1-13.

34. Camacho E, Israel A. Effect of Tempol and Apocynin on Rat Kidney Antioxidant Enzyme Activities in an Experimental Model of Preeclampsia. J Pharm Biol. 2015;5:185-93.

35. Ding W, Wang B, Zhang M, Gu Y. Tempol, a Superoxide DismutaseMimetic Drug, Ameliorates Progression of Renal Disease in CKD Mice. Cell Physiol Biochem. 2015;36:2170-82.

36. Katsuda Y, Ohta T, Miyajima K, et al. Diabetic complications in obese type 2 diabetic rat models. Exp. Anim. 2014;63:121-32.

37. Banday AA, Marwaha A, Tallam LS, Lokhandwala MF. Tempol reduces oxidative stress, improves insulin sensitivity, decreases renal dopamine D1 receptor hyperphosphorylation, and restores D1 receptor-G-protein coupling and function in obese Zucker rats. Diabetes. 2005;54:2219-26.

38. Esteghamati A, Eskandari D, Mirmiranpour H, Noshad S, Mousavizadeh M, Hedayati M, et al. Effects of metformin on markers of oxidative stress and antioxidant reserve in patients with newly diagnosed type 2 diabetes: a randomized clinical trial. Clin Nutr. 2013;32:179-85. doi: 10.1016/j. clnu.2012.08.006.

39. da Silva AR, Cerdeira CD, Brito AR, et al. Green banana pasta diet prevents oxidative damage in liver and kidney and improves biochemical parameters in type 1 diabetic rats. Arch Endocrinol Metab. 2016;60:355-366.

40. Zarling JA, Brunt VE, Vallerga AK, et al. Nitroxide pharmaceutical development for age-related degeneration and disease. Front Genet $2015 ; 6: 325$.

41. Thaler S, Fiedorowicz M, Rejdak R, Choragiewicz TJ, Sulejczak D, Stopa $\mathrm{P}$, et al. Neuroprotective effects of tempol on retinal ganglion cells in a partial optic nerve crush rat model with and without iron load.Exp Eye Res. 2010;90:254-60. doi: 10.1016/j.exer.2009.10.013.

42. Tada M, Yokoyama H, Toyoda Y, Ohya H, Ogata T, Kamada H. In vivo ESR study on hepatic reduction of a nitroxide radical after administration of glucose in rats. IUBMB Life. 2001;51:45-8.

43. Israeli A, Patt M, Oron M, Samuni A, Kohen R, Goldstein S. Kinetics and mechanism of the comproportionation reaction between oxoammonium cation and the hydroxylamine derived from cyclic nitróxides. Free Radic Biol Med. 2005;38:317-24.

44. Santos GB, Ribeiro AC, Lima SN, Trostchansky A, Cerdeira CD, Brigagão MR. Nitroxide Tempol down-regulates kinase activities associated with NADPH oxidase function in phagocytic cells and potentially decreases their fungicidal response. Chem Biol Interact. 2018;279:203-9. doi: 10.1016/j.cbi.2017.11.016.

45. Santos GB, Gonzalez-Perilli L, Mastrogiovanni M, Aicardo A, Cerdeira CD, Trostchansky A, et al. Nitroxide 4-Hydroxy-2,2',6,6'tetramethylpiperidine 1-oxyl (Tempol) inhibits the reductase activity of protein disulfide isomerase via covalent binding to the Cys 400 residue on CXXC redox motif at the a' active site. Chemico-Biological Interactions. 2017:272:117-24. 